Article

\title{
Social Values in Stimulating Organic Production Involvement in Farming-The Case of Poland
}

\author{
Karol Kociszewski ${ }^{1, *} \mathbb{0}$, Andrzej Graczyk ${ }^{1}$, Krystyna Mazurek-Łopacinska ${ }^{2}$ (]) \\ and Magdalena Sobocińska ${ }^{2}$ (D) \\ 1 Department of Ecological Economics, Faculty of Economics and Finance, Wroclaw University of Economics \\ and Business, 53-345 Wroclaw, Poland; andrzej.graczyk@ue.wroc.pl \\ 2 Department of Marketing Research, Faculty of Management, Wroclaw University of Economics and \\ Business, 53-345 Wroclaw, Poland; krystyna.mazurek-lopacinska@ue.wroc.pl (K.M.-L.); \\ magdalena.sobocinska@ue.wroc.pl (M.S.) \\ * Correspondence: karol.kociszewski@ue.wroc.pl; Tel.: +48-694-941-610
}

Received: 19 June 2020; Accepted: 21 July 2020; Published: 23 July 2020

check for updates

\begin{abstract}
The main research problem discussed in this paper involves evaluation of the motives of agricultural producers for pursuing and developing organic production. The aim of this study is to identify and evaluate the role of social values in stimulating decisions of involvement in organic production. Analytical observations were conducted on the basis of responses to surveys on a nation-representative sample in Poland (350 conventional farms and 70 organic farms in 2011; 260 conventional farms and 65 organic farms in 2019). Analyses were conducted in relation to the potential and perspectives for development of organic farming. They were focused on identifying the original motives for such decisions (incentives and disincentives). This allowed for effective evaluation of both the trend and the pace of the studied processes. The development potential of organic farming in Poland was estimated at $5-15 \%$ of the total number of farms. The most important factors encouraging farmers to take up production are associated with social values (care for the natural environment and family health). A significant chance for the development of organic production is the expected demand growth, which is also related to social values: the increasing environmental awareness and environmental change of consumption patterns.
\end{abstract}

Keywords: sustainable agriculture; organic farmers; social values; producer groups

\section{Introduction}

While decisions made by farmers do not necessarily result in the formation of enterprises designed to address specific social goals, it can be assumed that such goals may play the role of motivating factors in the transition into organic farming. In particular, decisions to pursue organic production seem to be strongly motivated by the perceived responsibilities of protecting the natural environment, preventing degradation of natural habitats, and fostering the social prestige and public reception of pro-environmental farming.

Social entrepreneurship refers to economic activities, the specific nature of which consists in the goal of the actions taken being determined in a manner that is different from the traditional one. Their goal is, above all, to create social values. They are achieved in market conditions while respecting the requirements of economic efficiency of the actions taken. Social value is intended to provide future benefits to the society as a whole. Identification of this particular determinant of entrepreneurship may proceed through verification of activities against the associated Sustainable Development Goals. Organic farming fulfils the postulates of the second goal: "End hunger, achieve food security and improved nutrition, and promote sustainable agriculture". According to the EU A Farm to Fork Strategy 
adopted in 2020, 25\% of the EU's agricultural land will be under organic farming by 2030 [1]. It is one of key elements of the European Green Deal which sets out how to make Europe the first climate-neutral continent by 2050. It is also associated with the EU Biodiversity Strategy for 2030. Most of the studies that compared biodiversity in organic and conventional farming demonstrated lower environmental impacts from organic farming [2]. According to the strategy, at least $40 \%$ of the total budget of the EU's common agricultural policy (CAP) will be intended for combating climate change. Producers should be rewarded more than ever for achieving environmental and climate goals with more success, including soil carbon management and storage, and for better nutrient management to improve water quality and reduce emissions. Covering the entire supply chain strategy is also intended to ensure food security, which is once more becoming an increasingly important contemporary challenge (climate crisis, pandemic, interruption of global supply chains). At the same time, it aims to relate to food safety, i.e., the supply of high-quality and safe food.

The aim of this paper is to demonstrate the extent to which social values affect the development prospects for the supply side of the organic farming market. To this end, the authors determined the outlook for increasing the production potential (number of farms) in Poland and the factors which influence that. The incentives and disincentives for farmers to take up organic production as well as the opportunities for and barriers to market development were specified. This enabled identification of social values among them. The results of the study from 2019 were compared against historical findings obtained from a comparable sample in the year 2011. They were supplemented with an analysis of data on real changes in the number of organic farms in Poland and the policy connected with agricultural subsidies.

The final part of the study provides observations related to general perception of producer groups by individual farmers and their readiness to join such groups. In Poland, agricultural activity is pursued by circa 1.4 million farms. Approximately $52 \%$ of them cover an area of no more than 5 ha. Such farms fulfil substantial social, economic, and environmental functions. The small scale of production, which is extensive, hinders the achievement of a satisfying level of economic efficiency. Owners of small farms, in order to reduce insecurity and enhance their competitive force, may come together in groups of agricultural producers. This particular problem will be elevated after Jan 1, 2021, with the formal introduction of group certification of products. This will form a strong incentive for the development of organized groups of organic agricultural producers and for the effective propagation of sustainable farming as a fundament for the creation of social value and provision of social benefits.

The top-down method of presentation was adopted in the paper. It is guided by the following principle: first, the problem is outlined, and next, the problem is specified in the context of organic farming. Part one describes the theoretical aspects of social values and social enterprises and, from this angle, social values in farms' activities. Part two discusses the issue of establishing producer groups in farming as a form corresponding to the idea of social enterprise. The results begin with demonstrating data on organic farming development in Poland and proceed to analyzing and evaluating the survey results referring to the place of social values in farmers' motivations to take up and continue organic production. The next results show the conditions of willingness to integrate in producers' groups.

Conclusions regarding the actions fostering the further development of organic farming in Poland were based on the survey results. They are important for sustainable agriculture development. The recommendations might prove relevant also for other countries. They concern primarily public support for establishing social enterprises. The coming together of organic farmers will increase their economic power in the market, popularize good practices, and permit the achievement of economies of scale.

The findings of this paper could be useful for better management of organic production not only in Poland but also in other countries with similar socioeconomic and environmental conditions, especially in the new EU member states (EU13). It could also contribute to improvement of the financial system of public support for organic farming. It refers to recommendations for economic (agricultural and environmental) policies related to the greening of consumption and production, 
with special consideration of rural development. This could be helpful for taking advantage of the opportunities associated with the From Farm to Fork Strategy, including the effective absorption of EU funds, in particular from the CAP.

\section{Materials and Methods}

The aim of this study was achieved owing to the analyses of secondary data and to the results of a Polish nationwide survey conducted with the application of the CATI (Computer Assisted Telephone Interview) method twice, i.e., in 2011 and 2019, in two groups of farmers: conventional farm owners and organic farm owners (holders of organic farming certificates). The secondary data gathered from Statistics Poland and from Agricultural and Food Quality Inspection showed the tendencies connected with the development of organic farming and producers' groups in these kinds of production in Poland. The interviews used in the empirical study were based on the concept and forms of the survey questionnaires prepared by the authors. The questions in the first group (conventional farmers) concerned the identification of their willingness to shift to organic production, considerations of the related decisions (including stimuli and barriers), and predictions of further development of organic farming. The answers from the second group of respondents (organic farmers) were based on their experiences connected with participation in the market. The findings gathered allowed the identification of the opportunities for and barriers to the development of organic farming and the considerations of its profitability. The authors compared the results from these two groups and from the two years in which the surveys were conducted. The next part of the study enabled the collection of opinions on the incentives and disincentives for organic production and development of producer groups. The results presented the opinions of farmers on economic, environmental, and social aspects of organic farming, including trainings on methods of production and administrative procedures.

In 2011, the survey covered 350 conventional farms (the ones not holding organic farming certificates) and 70 organic farms of above 1 ha (Utilized Agricultural Area-UAA) which pursued production activities. In 2019, the sizes of both groups were 260 and 65, respectively. In 2011, the authors, examining a population of Polish farms of 1.4 million, selected a representative sample. Using the formula for the minimum sample size $n=350$, with a standard error of $5 \%$ allowed the inference at the level of significance $\&=0.06$. In 2019, for economic reasons (limited financial resources available to the authors), we reduced the sample to $n=260$. The sample size $n=260$, with a standard error of $5 \%$, gave the possibility to infer at the level of significance $\&=0.1$ (with a probability of $p=0.1$ when inferred, the authors make a first-type error). For the test sample from $2019(n=260)$, the probability of a first-type error is slightly higher than for the 2011 sample, but with such big representative samples, the differences in the results are not statistically significant. Differences in sample size did not affect actual differences in the results. In addition, it is noteworthy that both samples allowed the authors to identify the processes in the studied populations and to assess the change in these patterns during the analysis period. In order to obtain representative results, both research samples were drawn on the basis of a random operation in the form of a database of Polish agricultural holdings owned by a specialized research institute, which, on behalf of the authors, carried out the surveys for the purposes of this article.

When determining the method of selecting individuals, the quota principle was adopted, as a result of which the distribution of the study sample over voivodships was similar to the actual situation in Poland in terms of proportion. The respondents were sampled such that the sizes of particular area groups were close to the actual area structure on the national scale. This ensures representativeness in the geographical and administrative layout. 


\section{Social Values and Social Enterprises in Farms' Activities}

\subsection{Theoretical Aspects of Social Values and Social Enterprises}

Social entrepreneurship is perceived as an integral part of the third sector, apart from the traditional private and public sectors. In accordance with the theory of public goods, as a result of the incapability of government institutions and market mechanisms, the gap may be bridged by non-profit organizations [3]. Other theories of the third sector refer to the public or semi-public nature and characteristics of goods and positive external effects the civil society or non-profit organizations generate for the entire society [4].

Social enterprises are organizations or firms which effectively respond to the practical and current needs of the present society in determining entrepreneurial actions and a particular type of governance [5]. Creating benefits for the community is characterized by a high level of autonomy with respect to the public sphere. This activity involves a considerable level of economic risk, limited distribution of profit, and participatory social management engaging various entities affected by the activity [6].

Social enterprises develop the supply side of the third sector. In establishing enterprises, social entrepreneurs are motivated by various goals, including social ones. They endeavor to introduce a change and, thus, create value. The distinction between a classical enterprise and a social enterprise is accurately identified by Martin and Osberg [7] (p. 35): "We believe that the critical distinction between entrepreneurship and social entrepreneurship lies in the value proposition itself. For the entrepreneur, the value proposition anticipates and is organized to serve markets that can comfortably afford the new product or service, and is, thus, designed to create financial profit. From the outset, the expectation is that the entrepreneur and his or her investors will derive some personal financial gain. Profit is sine qua non, essential to any venture's sustainability and the means to its ultimate end in the form of large-scale market adoption and ultimately a new equilibrium".

The social entrepreneur, however, neither anticipates nor organizes to create substantial financial profit for his or her investors-philanthropic and government organizations for the most part-or for himself or herself. Instead, the social entrepreneur aims for value in the form of large-scale, transformational benefit that accrues to a significant segment of society at large. Unlike the entrepreneurial value proposition that assumes a market that can pay for innovation and may even provide substantial upside for investors, the social entrepreneur's value proposition targets an underserved, neglected, or highly disadvantaged population that lacks the financial means or political clout to achieve the transformative benefit on its own. This does not mean that social entrepreneurs as a hard-and-fast rule shun profitmaking value propositions. Ventures created by social entrepreneurs can certainly generate income, and they can be organized as either not-for-profits or for-profits. What distinguishes social entrepreneurship is the primacy of social benefit. The US approach to social entrepreneurship presented here is consistent chiefly with Dennis Young's theory regarding social issues and perceives the entrepreneur as a social change factor.

The European approach to social entrepreneurship is characterized by using indicators enabling identification of a social enterprise based on the concise definition by Jacques Defourny [8]; it presents a "new entrepreneurial spirit focused on social aims". This covers three dimensions: economic, social, and a special type of management.

The criteria related to the economic and entrepreneurial dimension of initiatives are as follows:

(a) a continuous activity producing goods and/or selling services;

(b) a high degree of autonomy;

(c) a significant level of economic risk;

(d) a minimum amount of paid work.

The criteria of the social dimension of a social enterprise present:

(e) an explicit aim to benefit the community; 
(f) an initiative launched by a group of citizens or civil society organizations;

(g) a limited profit distribution.

The third portion of the criteria includes participatory governance of a social enterprise, which means:

(h) a high degree of autonomy;

(i) a decision-making power not based on capital ownership;

(j) a participatory nature, which involves various parties affected by the activity [6] (pp. 26-27).

As stated by Jacques Defourny [9], the indicators describe "ideal-type" conditions, which might enable the identification of an organization called a social enterprise.

Regardless of the US or European approach to social entrepreneurship, it can be assumed that the basic distinguishing feature of the establishment and operation of such enterprises is initiation of a change which generates a social value.

\subsection{Social Values in Farms' Activities}

In the early 21st century, social values generated by farms were looked at from the angle of "social agriculture", "green care farming", and "farming therapy" [10,11]. Attention was given mainly to "the use of commercial farms and agricultural landscapes as a base for promoting mental and physical health, through normal farming activity" [12] (p. 247). Notice was taken of the therapeutic effect of such an activity in farming and of the elements concerning human wellbeing. Consequently, sustainable agriculture is better than industrial agriculture because it does not have a negative impact on the rural population, impoverishing farmers and, thus, depriving them of opportunities for development [13]. In that context, there is the need for the balance between all three dimensions of sustainable development. Sulewski, Kłoczko-Gajewska, and Sroka [14] concluded that correlation and correspondence analyses showed that the farms reached the balance of environmental, economic and social dimensions simultaneously when the level of sustainability indices was medium, while a high level of sustainability in one dimension made it very difficult to reach a high level in the others. It was also emphasized that assessing farms' sustainability with the use of a simple aggregation of variables may be not correct, since sustainability goals may compete with each other. It revealed that farms characterized by a medium level of sustainability in one dimension usually achieved medium levels in other dimensions, while farms characterized by a high level of one dimension were less likely to reach a high level in any other dimension. Bacon, Getz, Kraus, Montenegro, and Holland [15] found that the spread of diversified farming systems (DFS) can begin to reprioritize local knowledge, ecology, and social development. Supported by people and the institutions they create, DFS can contribute to broader efforts that seek to improve the quality of rural life, assure workers' rights, enable rural democracy, conserve biodiversity, and sustain cultural traditions.

The research by Hudcova, Chovanec, and Moudry [16] shows that social farms in the agricultural sector participate in ensuring sustainability of sites and maintaining traditional farming systems. The development of rural areas in the activities taken by social farmers consists primarily in preserving the traditional nature of diversified agriculture, environmental protection, and environmental diversity. Organic farms fall into a special category. Studies on organic farming present divergent views on sustainable development and the potential of contributing to global food security [17]. What is of particular importance is lower efficiency of organic farming in comparison to conventional farming [18]. The differences become less significant when the social aspects of using local resources (i.e., local seeds, varieties, manure) by organic farming, benefits for animal wellbeing, and possibilities to increase the number of farmers are taken into account $[19,20]$.

Numerous studies oriented towards the environmental and economic dimensions of sustainable development have been conducted in recent years. However, much less space was dedicated to the social dimension of sustainable development in the relevant literature [21]. Moreover, this strand of 
the literature is highly focused on specific research contexts rather than on all aspects of sustainable social development [22].

There are two perspectives that are applied for assessing the social aspects of organic farming:

- Internal social sustainability (i.e., at the organizational level);

- External social sustainability (i.e., at the territorial level) [23].

The studies of the internal dimension concern various problems. Dillon et al. [24] examined the achievements in the educational dimension based on an increase in the share of qualified personnel. Job creation was assessed by Manara and Zabaniotou [25], with the growth in the number of employees taken into consideration. The effects of internal training were assessed, among others, by Amaral and La Rovere [26] as well as Veldhuizen et al. [27], based on the increased number of jobs and hours of training per employee per annum. The effects of professional activation of women were determined by Mani et al. [21] by means of assessing women's share in the employment structure.

The research on the external dimension of social development regarded, among others, employment [21], unemployment rate, and education level [22,26] (an increased share of people with secondary or tertiary education). An interesting issue to examine is the extent to which agricultural production transformation contributes to achieving social effects.

With the application of indicators for measuring social dimensions of organic farming, Torres et al. [28] carried out comparative research and found that, from the viewpoint of sustainable social development, restructuring of the citrus sector towards organic farming in the Bajo Andarax region resulted in a significant improvement of employment (indicators both at the farm level and at the municipality level) in comparison to the reference territories of the province of Almería and the region of Andalusia. This improvement, however, did not result in an increase in the qualification level of the workforce of the farmers' association relative to the reference territories. Moreover, no significant differences were found in terms of workforce gender and education level in the municipalities. Nevertheless, the characteristics of users (managers) of farms-gender, age and education-are included in indicators of the human factor as the crucial element in the assessment of suitability [29]. The results of that study revealed the influence of organic farming on external social sustainability but not on the internal one. A part of our surveys considered public measures aimed at improvement in that dimension of sustainable agricultural and rural development. This referred to the training on organic farming.

The social motives for farmers' efforts to convert into organic farming vary. The problem of the social aspects of sustainable agricultural development has been the subject of many studies. They stated, inter alia, that organic farmers are less risk averse as conventional farmers [30]. Older farmers are less willing to convert, are mostly less educated, and are not so ambitious anymore. These authors identified important aspects of relevance for Swedish (livestock) farmers' social situation and compared these aspects with social indicators [31,32]. A survey revealed that social issues of key importance for the self-reported overall life satisfaction of Swedish livestock farmers are: having a good financial situation, having a similar standard of living as others, not experiencing too much stress, having meaningful work, having decent working hours, and having a desirable family situation [33]. The social aspect is most often measured by the level of education, experience and skill in farming, social status of the family, ways of supporting decision making, living conditions, involvement in community issues, safety, etc. [14]. The social motives for promoting sustainable agriculture presented in the literature concern internal aspects relating to the stakeholders themselves as well as social motivations about the external conditions identified as important in research, indicating the quality of employment, qualifications, and education, as well as human and social capital in a broad sense. They are strongly linked to social sustainability, as they have a direct impact on the income of the agricultural population [34,35]. According to research conducted in Norway, all the surveyed groups of Norwegian farmers as less important goals ranked "higher private consumption", "increasing equity", and "social contacts". Among the motives for the decision to start organic production, they indicated to "produce high quality food" as the most important one [36,37]. 
The literature reveals that the "social" was integrated late into debates on sustainable development. Eizenberg and Jabareen [30] suggest that risk is a constitutive concept of sustainability and that the contemporary conditions of risk resulting primarily from climate change and its ensuing uncertainties pose serious social, spatial, structural, and physical threats to contemporary human societies and their living spaces. Within the framework of sustainability, we propose that social sustainability strives to confront risk while addressing social concerns.

The examination of the social motives of farmers deciding to re-profile production and run organic farms is, therefore, a contribution to filling this research gap. The problem of social motivation of farmers is analyzed in the example of Poland. However, it could also concern new EU member states (EU13). Their farms do not make a positive contribution big enough to social sustainability, considering the relation between the inputs (unpaid labor input, paid labor input, wages paid) and the results obtained (farm net income) in agricultural activity [37]. Due to the conditions (low degree of chemical soil contamination, high population in agricultural regions), there are favorable conditions for conversion into organic agriculture. However, it is necessary to adapt the EU's policy to the conditions of sustainability in a way defined in the European Commission's document A Framework for Indicators for the Economic and Social Dimensions of Sustainable Agriculture and Rural Development [38]. It underlined that "economic, social and environmental objectives can to a certain degree develop synergies. However, they are not always mutually supportive; they even can compete with each other. Where this is the case, the concept of sustainability refers to the need to strike the right balance between its three elements. Political choices concerning one out of these three elements must at least ensure that certain minimum standards with respect to the other two are observed". The economic measures of the CAP contain socially inclusive provisions, such as support for small farmers, redistributive payments, early retirements for farmers, trainings, and other measures within socially oriented parts of rural developments programs (they also consist of economic and environmental elements). The environmental actions of the CAP are also designed to be socially sustainable. Consequently, the support for organic farming plays an important role in the second pillar of the CAP (rural development).

\section{Results}

The respondents were selected in such a way that the number of responded farms divided according to their size (UAA) was similar to the actual structure on a national scale (Table 1). This refers to both groups of farms and to both surveys (2011 and 2019).

Table 1. Statistical distribution of responded farms divided according to their size in comparison to the actual state.

\begin{tabular}{|c|c|c|c|c|c|c|c|c|}
\hline \multirow{3}{*}{$\begin{array}{c}\text { Farm } \\
\text { Area } \\
\text { (UAA): }\end{array}$} & \multicolumn{4}{|c|}{ Conventional Farms } & \multicolumn{4}{|c|}{ Organic Farms } \\
\hline & \multicolumn{2}{|c|}{2011} & \multicolumn{2}{|c|}{2019} & \multicolumn{2}{|c|}{2011} & \multicolumn{2}{|c|}{2019} \\
\hline & $\begin{array}{l}\text { Surveyed } \\
\text { Farms }\end{array}$ & $\begin{array}{c}\text { Actual } \\
\text { State }\end{array}$ & $\begin{array}{l}\text { Surveyed } \\
\text { Farms }\end{array}$ & $\begin{array}{c}\text { Actual } \\
\text { State }\end{array}$ & $\begin{array}{l}\text { Surveyed } \\
\text { Farms }\end{array}$ & $\begin{array}{c}\text { Actual } \\
\text { State }\end{array}$ & $\begin{array}{l}\text { Surveyed } \\
\text { Farms }\end{array}$ & $\begin{array}{c}\text { Actual } \\
\text { State }\end{array}$ \\
\hline $1-5$ ha & $59.70 \%$ & $57.80 \%$ & $50.80 \%$ & $51.50 \%$ & $24.30 \%$ & $21.40 \%$ & $20.00 \%$ & $21.00 \%$ \\
\hline 5-10 ha & $19.80 \%$ & $20.70 \%$ & $22.70 \%$ & $22.10 \%$ & $24.30 \%$ & $23.30 \%$ & $21.50 \%$ & $18.10 \%$ \\
\hline 10-20 ha & $13.90 \%$ & $14.10 \%$ & $16.20 \%$ & $14.90 \%$ & $15.70 \%$ & $24.60 \%$ & $24.60 \%$ & $25.70 \%$ \\
\hline $20-50$ ha & $5.70 \%$ & $7.90 \%$ & $7.70 \%$ & $7.40 \%$ & $22.90 \%$ & $17.40 \%$ & $21.50 \%$ & $22.60 \%$ \\
\hline$>50$ ha & $0.90 \%$ & $1.50 \%$ & $2.70 \%$ & $2.20 \%$ & $12.80 \%$ & $13.30 \%$ & $12.30 \%$ & $12.60 \%$ \\
\hline
\end{tabular}

Source: Authors' own study based on surveys and data published by Statistics Poland [39,40] and IJHARS (Inspekcja Jakości Handlowej Artykuów Rolno-Spozywczych (in Polish); Agricultural and Food Quality Inspection (In English)) [41,42].

The characteristics of organic and conventional farmers (Table 2) contain some social features which could be useful to explain characteristics of labor force driving forces for transition into organic farming (see Section 6). 
Table 2. The characteristics of surveyed farms (\% response).

\begin{tabular}{|c|c|c|c|c|}
\hline \multirow{2}{*}{ Specification } & \multicolumn{2}{|c|}{ Conventional Farmers } & \multicolumn{2}{|c|}{ Organic Farmers } \\
\hline & 2011 & 2019 & 2011 & 2019 \\
\hline \multicolumn{5}{|c|}{ The structure of respondents due to their Education level: } \\
\hline Primary & $15.10 \%$ & $2.30 \%$ & $8.60 \%$ & $3.10 \%$ \\
\hline Vocational, agricultural & 16.3 & 10.8 & $11.40 \%$ & $16.90 \%$ \\
\hline Vocational, other than agricultural & $27.40 \%$ & $22.30 \%$ & $10.00 \%$ & $3.10 \%$ \\
\hline Secondary, agricultural & $11.70 \%$ & $18.50 \%$ & $28.60 \%$ & $26.20 \%$ \\
\hline Secondary education, other than agricultural & $22.60 \%$ & $28.80 \%$ & $15.70 \%$ & $16.90 \%$ \\
\hline University higher, agricultural & $1.40 \%$ & $7.70 \%$ & $7.10 \%$ & $23.10 \%$ \\
\hline University higher, other than agricultural & $5.40 \%$ & $9.60 \%$ & $18.60 \%$ & $10.80 \%$ \\
\hline \multicolumn{5}{|l|}{ Age structure: } \\
\hline $21-30$ years old & $3.70 \%$ & $1.90 \%$ & $5.70 \%$ & $3.00 \%$ \\
\hline $31-40$ years old & $8.90 \%$ & $21.90 \%$ & $14.30 \%$ & $16.20 \%$ \\
\hline $41-50$ years old & $28.60 \%$ & $38.10 \%$ & $37.10 \%$ & $42.30 \%$ \\
\hline $51-60$ years old & $33.70 \%$ & $27.30 \%$ & $30.00 \%$ & $30.30 \%$ \\
\hline Over 61 & $25.10 \%$ & $10.80 \%$ & $12.90 \%$ & $8.20 \%$ \\
\hline \multicolumn{5}{|l|}{ Number of workers: } \\
\hline $1-5$ & $98.00 \%$ & $94.60 \%$ & $92.90 \%$ & $89.30 \%$ \\
\hline $6-10$ & $2.00 \%$ & $5.40 \%$ & $7.10 \%$ & $10.70 \%$ \\
\hline \multicolumn{5}{|l|}{ Production purpose: } \\
\hline For own needs only & $53.70 \%$ & $14.30 \%$ & $55.40 \%$ & $21.50 \%$ \\
\hline For sale and for own needs & $46.30 \%$ & $85.70 \%$ & $44.60 \%$ & $78.50 \%$ \\
\hline
\end{tabular}

Source: Authors' own study.

The production profile of responded farms (Figure 1) includes both animal breeding (cattle, pigs, poultry, sheep) and crops (cereals, sugar beet, fruit, vegetables). It can be seen that among organic farms, there are more holdings with cultivation of fruits and vegetables than among conventional farms. At the same time, the number of organic farms with pig production is significantly smaller than among conventional farms.

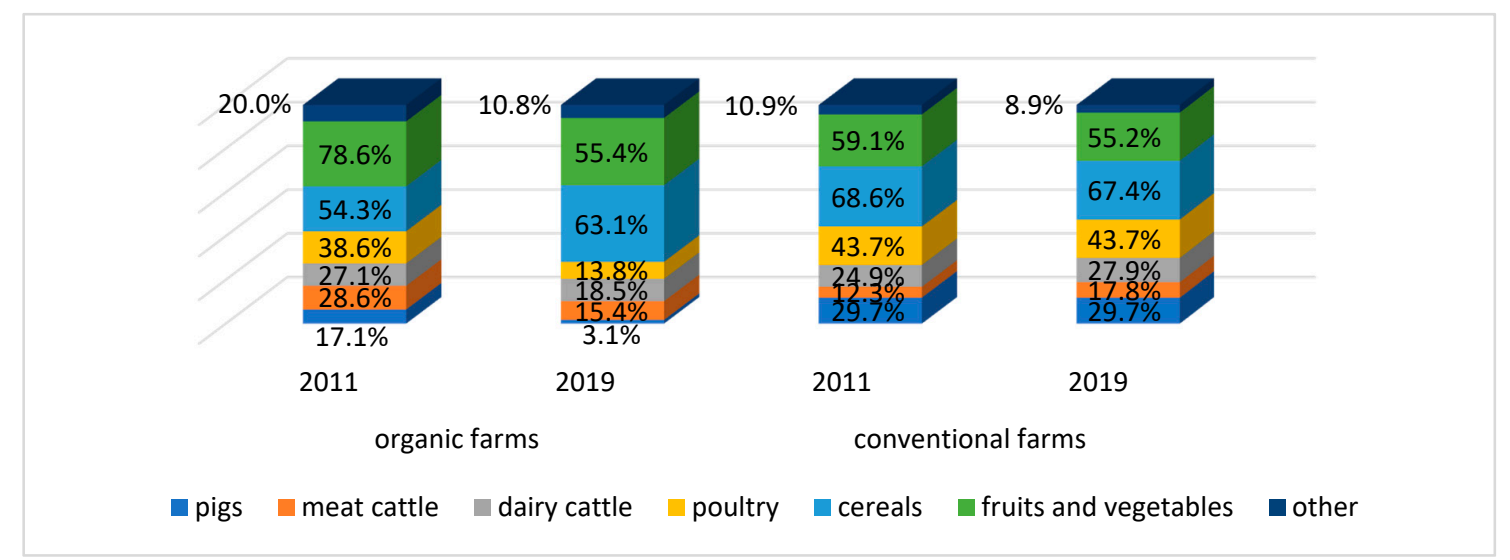

Figure 1. Production profile of surveyed farms. Source: Author's own elaboration.

In 2011, the number of organic farms with dairy and meat cattle was bigger than and in conventional ones. In 2019 the situation reversed. The results of the survey carried out in 2019 indicate that $3.5 \%$ of the farmers want to make the shift in their farms into organic farming methods in whole and $1.5 \%$-in part. Apart from that, $10 \%$ of the respondents are interested but indeterminate about commencing organic production (Figure 2). 


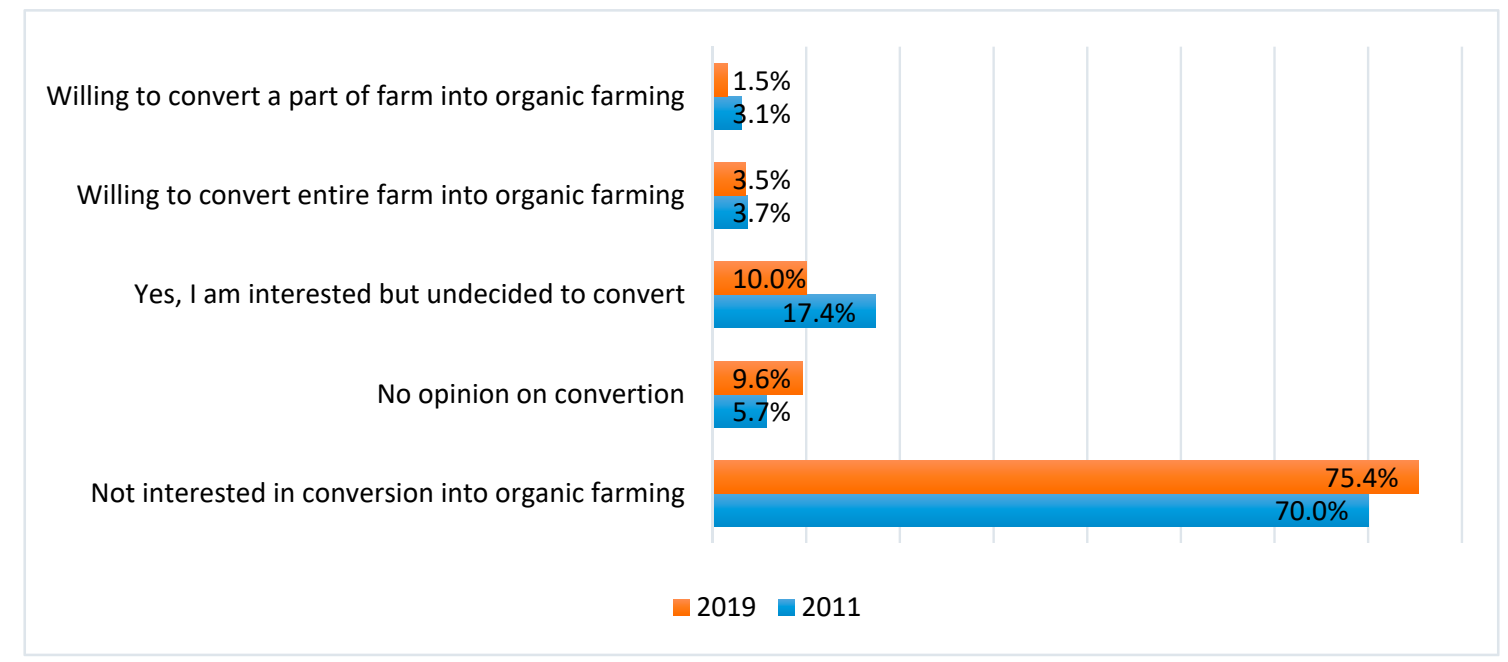

Figure 2. Willingness to convert into organic farming among conventional farmers. Source: Author's own elaboration.

In 2011, the farmers declaring the conversion of the whole farm or part of it into organic farming usually enumerated care for their own and their families' health ( $87.1 \%$ of the answers), care for the environment $(78.6 \%)$, and satisfaction from work $(65.7 \%)$ among the incentives to do that (Figure 3).

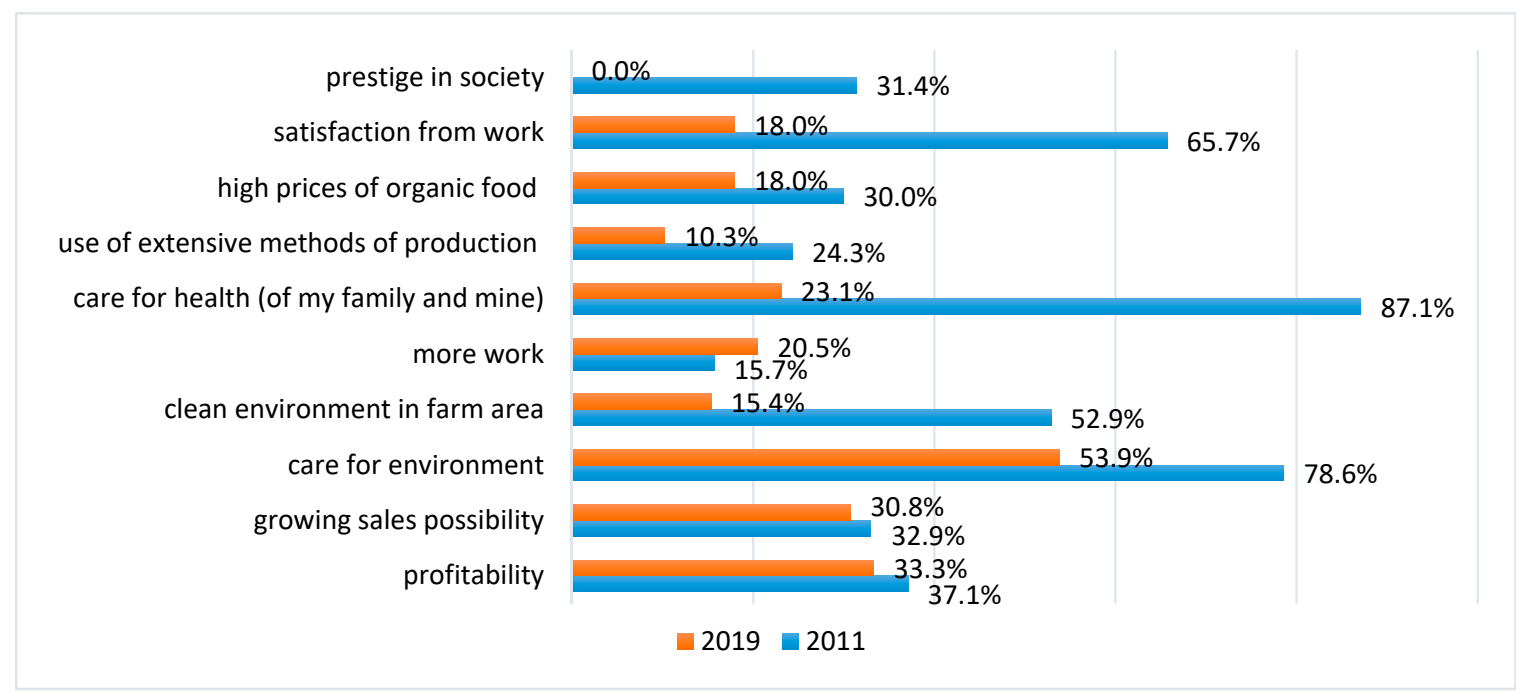

Figure 3. The incentives of conversion into organic farming according to the owners of conventional farms (\% of responses). Source: Authors' own study.

In 2019, the most frequently indicated motive was care for the environment (53.85\%), and the two remaining motives lost their significance ( $23.08 \%$ and $17.95 \%$, respectively).

Production profitability (33.33\%) and increasing sales possibilities (30.77\%) were listed second and third among the factors enhancing the willingness to commence organic production. No one pointed to increased prestige in society (in the survey of 2011, this motive was mentioned by $31.4 \%$ of the respondents).

The results of the survey carried out among organic farmers in 2011 also implied the critical significance of the factors associated with social values in making the decision on converting to organic farming methods (Figure 4). Care for their own and their families' health, care for the environment, satisfaction from work, and prestige in society were the top four most frequent responses. Economic factors played a smaller role in the farmers' decisions. Production profitability was ranked as low as fifth and sales possibilities and high prices of products came seventh. In accordance with the 
findings of 2019, care for the environment turned out to be the strongest motive for commencing organic production. Its significance grew relatively compared to the results of 2011, when it was ranked second in terms of frequency of organic farmers' responses. In 2019, the motive concerned with clean environment in the farm area came second (53.85\%). Its importance grew also in relation to other factors; it was ranked fifth in the previous survey. In the organic farmers' opinions, the possibility to use workforce in organic farming is highly significant $(43.08 \%$, third place).

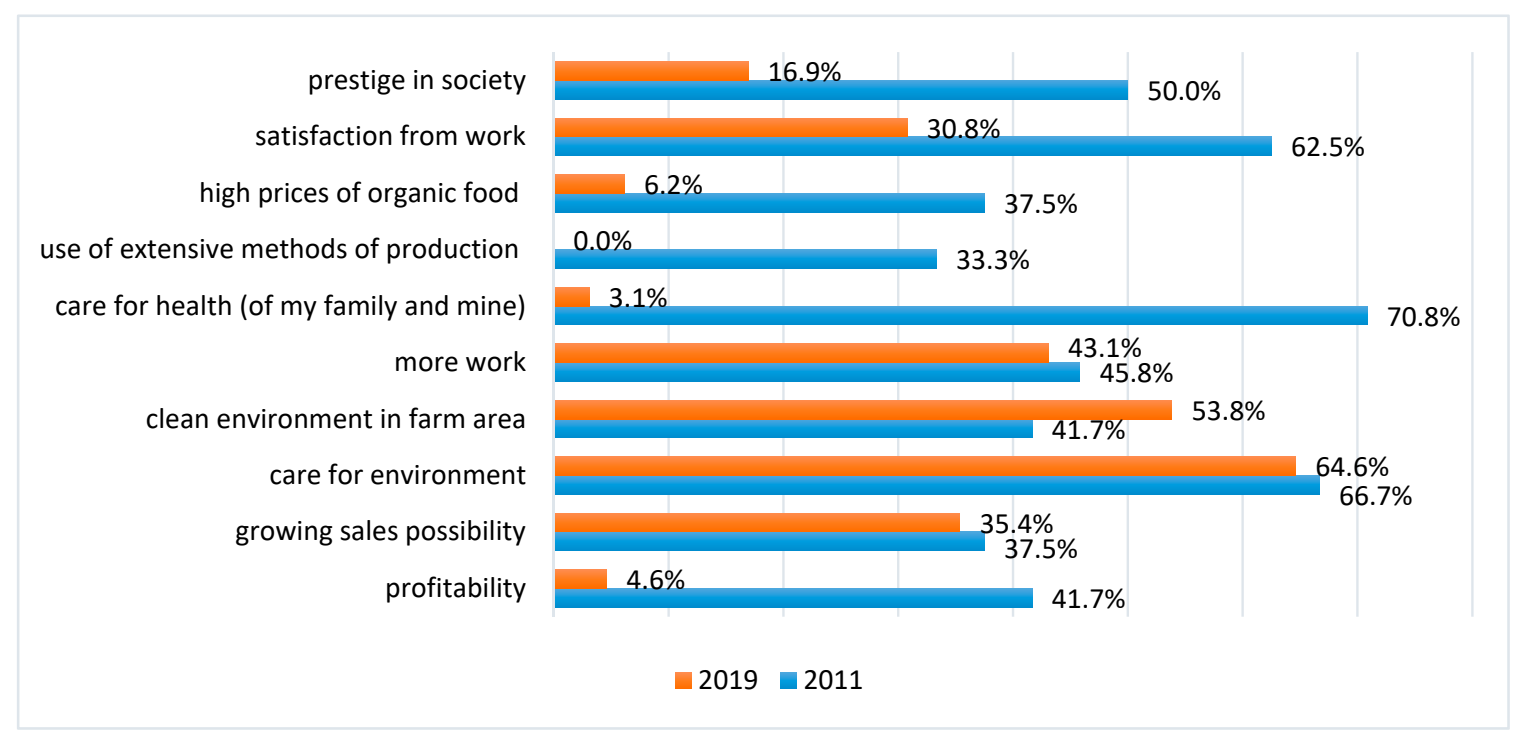

Figure 4. Incentives to convert the farm into organic production according to the owners of organic farms (\% response). Source: Authors' own study.

The unfavorable assessment of the economic considerations of organic production is confirmed in the results of the survey of the factors discouraging from organic production (Figure 5). In 2011, the farmers who were not interested in commencing it pointed to low production profitability $(15.1 \%)$, high labor costs $(14.8 \%)$, limited sales possibilities (13.8\%), and supply considerations (associated with high costs of production and low yields). In accordance with the findings of 2019, low production profitability and high labor costs were mentioned by a much higher number of farmers than the remaining factors discouraging organic production. In both surveys, a small number of respondents pointed to the fact that the disincentives included lack of interest in environmental protection and pollution in the farm area.

Most of the observations of the factors discouraging from taking up organic production (Figure 5) are reflected in the assessment of the barriers to further development of organic farming (Figure 6). This refers in particular to economic factors, including the low profitability of production (according to conventional farmers, the second greatest barrier to development in terms of frequency of indications, and according to organic farmers-the third one), its high costs, and considerable labor input. The greatest barriers to development are, however, the poor distribution system and bureaucratic obstacles.

Questions about the opportunities for organic farming development in Poland were asked to both groups in 2011 and 2019 (Table 3). In all answers given in 2019, it is visible that the respondents pointed to a given factor as a chance for development much less frequently than it was in 2011. This corresponds to the reduced percentage of those who declare commencing organic farming (Figure 2). In 2011, the farmers running conventional farms held the opinion that the greatest opportunity for the development of organic farming was EU subsidies. The farmers saw the chance in the increase in their rates. In 2019, it was the second greatest opportunity in terms of frequency of answers, but it was chosen by a considerably smaller number of the respondents (by 37.5 percentage 
points). A similar difference in assessment is noticeable in the findings of the survey conducted among organic farmers.

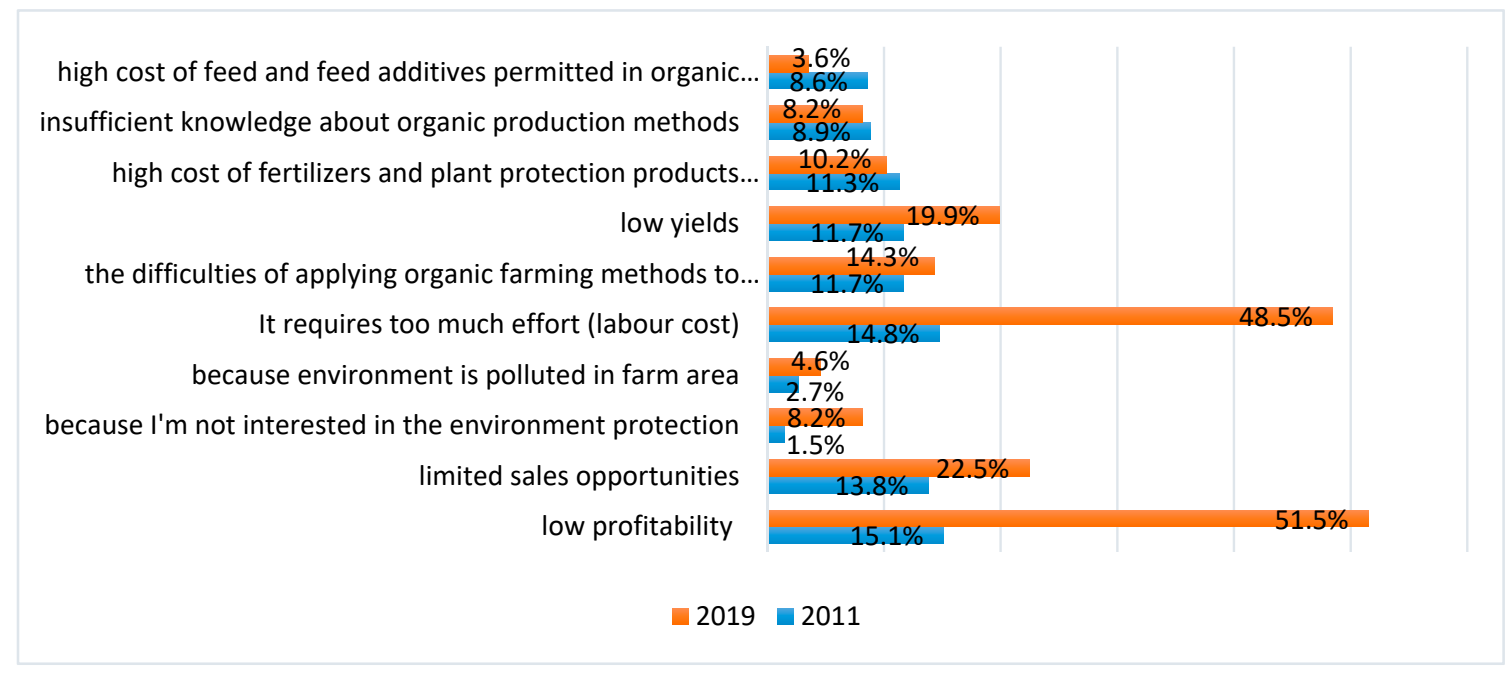

Figure 5. Disincentives to convert the farm into organic production (\% of responses among the owners of conventional farms). Source: Authors' own study.

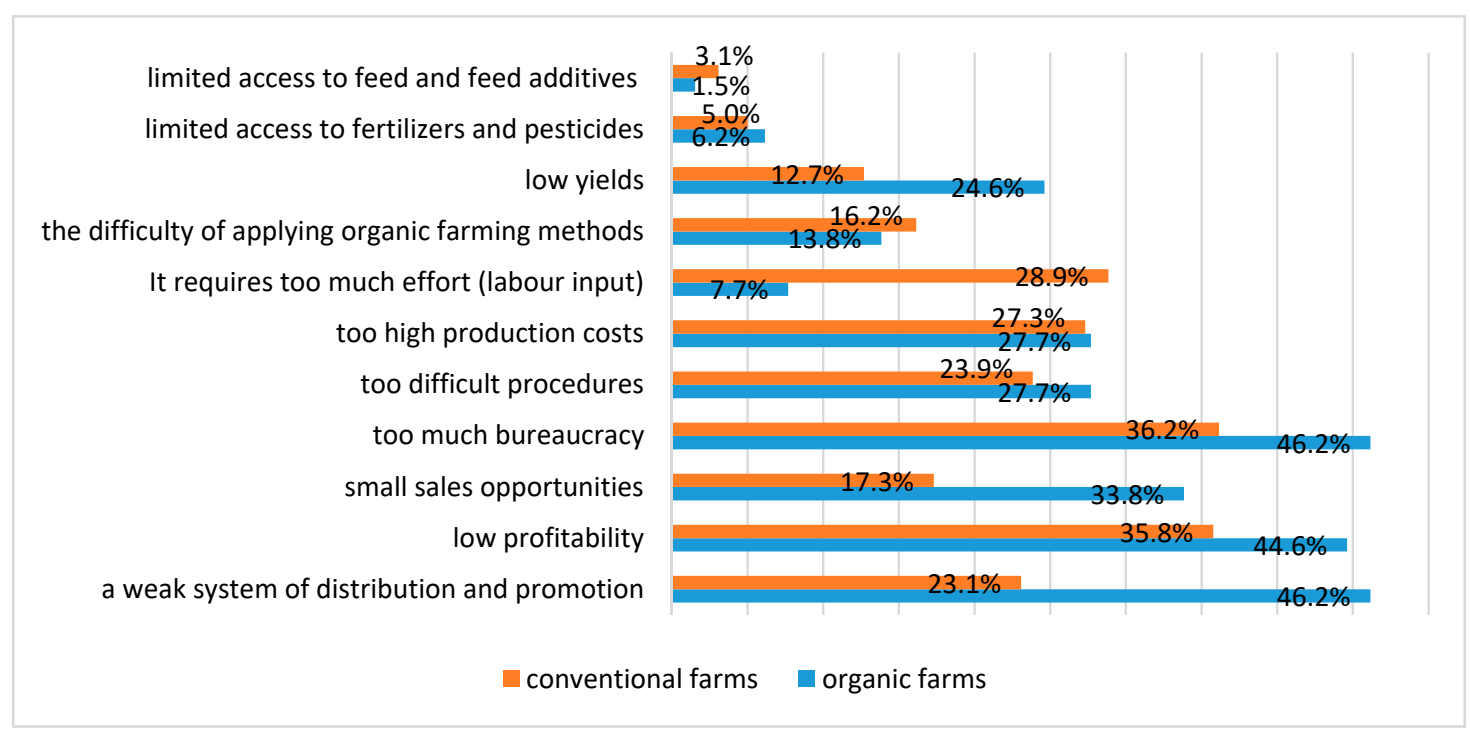

Figure 6. Barriers to development of organic farming according to the answers from 2019 (\% responses among holders of conventional and organic farms). Source: Authors' own study.

It is worth noting that, according to conventional farm owners, the responses that development opportunities resulting from demand growth and changes in the consumer awareness and attitudes towards the environment came second and third in terms of frequency of selection in 2011. In 2019, a remarkably lower number of respondents in this group perceived growth in demand as an opportunity for organic farming, yet, on the other hand, the increasing environmental awareness among consumers was indicated as a chance by the highest number of respondents. Farmers may fail to notice the dynamically growing demand, but they see the prospects for its growth in the future. Environmental awareness among consumers was the greatest chance for development according to organic farmers both in 2011 and in 2019. In this group, the second most often indicated opportunity was the growing demand in both years. The third one was popularity of organic consumption patterns.

In $2011,64.3 \%$ of organic farm owners pointed to the need for higher subsidies. In 2019, such indications were notably more frequent, i.e., $75.4 \%$. There were $45.4 \%$ of the conventional farmers 
in 2011 and $55.4 \%$ in 2019 who claimed that the rates of subsidies per 1 hectare of organic production should be higher. The next area of public support is connected with trainings on organic agriculture organized for farmers. In 2019, 38.5\% surveyed organic farmers took part in them ( $88.6 \%$ in 2011 ) of which $94.1 \%$ assessed them as valuable (93.8\% in 2011). In 2019, $26.2 \%$ respondents did not have the possibility to do that and $35.3 \%$ did not want to because, in their opinion, they were useless (in 2011, we did not ask why did they not attend trainings). Among conventional farmers, $10.4 \%$ took part in these trainings in 2019 (11.7\% in 2011), of which 85.5\% found them valuable (79.7\% in 2011). In 2019, $63.1 \%$ of respondents did not want to take part in trainings because they were useless and $26.5 \%$ did not have possibility of attendance.

Table 3. The chances of development of organic production. (\% response).

\begin{tabular}{lcccc}
\hline \multirow{2}{*}{ Specification } & \multicolumn{2}{c}{ Conventional Farmers } & \multicolumn{2}{c}{ Organic Farmers } \\
\cline { 2 - 5 } & $\mathbf{2 0 1 1}$ & $\mathbf{2 0 1 9}$ & $\mathbf{2 0 1 1}$ & $\mathbf{2 0 1 9}$ \\
\hline Growing demand & $49.9 \%$ & $20.4 \%$ & $62.9 \%$ & $52.31 \%$ \\
Better distribution & $47.8 \%$ & $26.5 \%$ & $52.9 \%$ & $15.38 \%$ \\
Growing environmental awareness of consumers & $63.1 \%$ & $29.6 \%$ & $84.3 \%$ & $67.69 \%$ \\
EU subsidies & $64.0 \%$ & $26.5 \%$ & $47.1 \%$ & $18.46 \%$ \\
Favorable policy of Polish authorities & $45.2 \%$ & $15.8 \%$ & $60.0 \%$ & $12.31 \%$ \\
Popularity of organic consumption patterns & $49.9 \%$ & $11.9 \%$ & $55.7 \%$ & $52.31 \%$ \\
\hline
\end{tabular}

Source: Authors' own study.

Public support could be an incentive for farmers to establish producer groups. Its effect was the growing interest in this form of agricultural activity observable in Poland beginning from 2000. The survey conducted by the authors of this paper in a representative group of Polish farmers in 2019 indicates that the share of farmers belonging to the producer group or intending to join such a group did not differ depending on the production profile (see Table 4). In the group of conventional farmers declaring such options, there were $11.5 \%$ of the respondents, and in the group of organic farmers $-12.3 \%$. It is worth noting that from among the surveyed farmers, the share of those who had already joined a producer group is greater.

Table 4. Share of answers given by the surveyed farmers to the question: Are you a member of a producer group or are you going to join such a group? (\% response).

\begin{tabular}{lcc}
\hline \multicolumn{1}{c}{ Answer Version } & Conventional Farmers & Organic Farmers \\
\hline $\begin{array}{l}\text { I am not a member of a producer group and I am not going to } \\
\text { join such a group }\end{array}$ & 75.4 & 78.5 \\
I am not a member of a producer group but I would like to join & 13.1 & 9.2 \\
such a group, yet I do not have such an option & & 1.5 \\
I am not a member of a producer group but I am not going to & 3.8 & 10.8 \\
join such a group and I have or will have such an option & 7.7 & 100.0 \\
Yes, I am & 100.0 & \\
\hline In total & & \\
\hline
\end{tabular}

Source: Authors' own study.

The sales of products to the market through a producer group was declared by $4.2 \%$ of conventional farmers. From among organic farmers, $7.8 \%$ of the respondents had sold their products through a producer group before they shifted to organic farming. In the period under examination, these were merely $10.5 \%$ of organic farmers. This group declares also a greater interest in this sales channel in the future (12.3\% of the respondents). This implies the existence of non-economic motivations for using this form of sales, since only $7.0 \%$ of the respondents indicated that this method was most profitable. 


\section{Discussion}

It is worth noting that among farms using organic methods, there are more medium-sized ones (20-50 ha) and large ones (over 50 ha) than among conventional farms (Table 1). In most developed countries (including the EU members), organic farms are larger than the other, and so, the situation observed in Poland is similar. The participation of larger farms in organic production can contribute to increase its effectiveness-under the condition that these farms provide their products on the market. In 2019, surveyed organic farmers produced less pigs, dairy, and meat cattle than in 2011, mainly because of the limited possibilities of sale for milk and meat products to the Polish distribution system. This could mean that a relatively small number of food processing plants is one of the barriers to the development of the market—especially in relation to meat and milk (Figure 1). It also reflects the actual situation of Polish organic farming - the conditions of production in organic farms occurred to be less favorable compared to other Polish farms. Productivity of dairy cattle was on a much lower level [43]. However, it is also worth noting that, in 2019, a much bigger percentage of organic farmers responded that they produced for sale on the market than in 2011. It could mean that-as mentioned above-the general number of organic farms is decreasing (from 2013) but the ones which continue production are more market-oriented. In both groups of respondents, the majority of farms engage a small number of people (up to 5 persons). In 2011, this result was achieved in $93 \%$ of organic farms (89\% in 2019) and $98 \%$ of conventional farms (94.6\% in 2019) and may be the consequence of the fact that organic farms are larger than the conventional ones (Table 1).

By comparing the two groups of farms, it can be seen that among organic farmers, there are more young people than among conventional farms (Table 2). As regards the age of users of conventional farms, the aging process is in progress [29], so a relatively bigger number of young farmers could be one of handicaps for organic farming. As was mentioned in Section 3.2, organic farmers are less risk averse as conventional farmers and older farmers are less willing to convert into organic farming [30]. The age structure is one of the characteristics of social sustainability. Another one is education [14], so it could be noticed that the organic farmers are higher educated than the others. Among them, there are more people with secondary education and higher education, including agricultural studies. Presented data may indicate that younger, better qualified, and more environmentally conscious people are more likely to be innovative (organic methods and certification in this respect may be regarded as innovative behavior). Such persons are better able to see the benefits from organic production and are willing to apply for agri-environment payments or other support for organic farming, which are more specific and harder to obtain than other subsidies.

A comparison of the 2011 and 2019 results shows a reduction in the potential for the further development of this type of farming from $6.8 \%$ to $5 \%$ of the total number of Polish farms (Figure 1 ). It is worth noting here that the potential decreased among the farmers who wanted to make a partial shift and increased among those who wanted to convert entirely to organic methods. The latter group might constitute the so-called hard core for the development of the supply side of the market of organic agricultural products. The percentage of the interested yet undecided to commence organic production dropped from $17.4 \%$ to $10 \%$. These changes could arise from the fact that farm owners were discouraged from organic production by the variable operating conditions of organic farming in Poland. The number of farms increased from 23.5 thousand in 2011 [44] to 26.6 thousand in 2013 [45]. The share of organic farms in the total number of farms grew from $1.4 \%$ to $1.9 \%$ [46]. The year 2013 saw a reversal of the upward trend regarding the number of farms, which increased by 24.8 thousand (by 1078\%) in the period 2003-2013. From that year, the number of organic farms dropped by 6000 (by $24.3 \%$ ) in the period 2013-2018 [47]. In 2019, the organically farmed areas constituted $3.4 \%$ of the UAA in Poland [42] and $7.2 \%$ of the UAA across the EU [48].

In this situation, among the factors which contributed to the reduced willingness of farmers to take up organic production, attention should be paid to the policy pursued by the Polish authorities and organizations concerned with organic farming support; it was inconsistent and disorganized. The decrease in the number of farms could have resulted from the tightening of procedures for the 
purpose of reducing abuse when applying for subsidies. The disincentives for farmers were frequent and chaotic amendments to regulations (e.g., regarding the requirements for products delivery to the market, IT systems, and administrative control) [49], which reinforced the sense of insecurity among beneficiaries and caused bureaucratic obstacles (this problem is included in the results of the survey presented in the further part of this paper). Additionally, there were delays in disbursement of subsidies.

Based on the 2011 results, the development potential of organic farms could be expected to increase from $1.4 \%$ to between ten and twenty percent of the share in the total number of farms, and so as to reach the level recorded in countries with highly developed organic farming, e.g., in Germany (the certificate was held by $11 \%$ of the total number of farms in 2017) [50]. In 2018, the number of organic farms in Poland was 19.2 thousand, which was $1.3 \%$ of all farms. The total number of Polish farms decreased to 1.4 million by 2018 [28]. The results of the survey of 2011 (Figure 2) showed that it was social values (care for family health, care for the environment, satisfaction from work) rather than economic factors in the narrow sense (production profitability, sales possibilities, high prices of organic products, and possibilities of using labor resources) that were more important in motivating conventional farmers to take up organic production. Similarly, in 2019, the crucial motive was associated with social values (care for the environment). This is consistent with findings on social values in farming presented in the theoretical background [10] (p. 247). The answers indicating disincentives to convert the farm into organic production confirm that the economic factors are perceived as unfavorable ones (Figure 4). This might result from more pragmatic attitudes presented by farmers who, being more knowledgeable and experienced in the area of organic product market development, began to take more notice of the related difficulties to achieve economic benefits. A relatively small number of conventional farmers indicated social values related to the quality of the environment as the disincentives to convert to organic farming.

The outcome of the survey examining conventional farmers concerns observations and predictions of the market in which they do not participate directly but would like to participate. The results obtained among owners of certified farms reflect their experiences as entities operating in the market. In this context, they prove the high significance of social values, in particular, environmental ones as incentives to convert to organic production (Figure 3). The results gathered among organic farmers in 2011 showed that care for families' health, care for the environment, satisfaction from work, and prestige in society were stronger incentives for organic production than economic factors (profitability, sales possibilities, high prices of products). The answers could have resulted from the farmers' avoiding presenting their attitudes as being oriented mainly towards financial factors. They might have wanted to say that they were guided by the "instinct of workmanship" as described by T. Veblen [51]. According to the findings of 2019, in comparison to the findings of 2011, significance of the care for the environment and clean environment in the farm area increased. This confirms the results of the study of Hudcova, Chovanec, and Moudry [16] indicated in the literature review, which showed that social farms in the agricultural sector participate in ensuring sustainability. Organic farmers are, however, less satisfied with work and experienced prestige in society to a smaller extent. These social values connected with internal social sustainability [24] occurred to be less important than they were according to the research from 2011. In addition, the number of answers pointing to the motivation related to care for health decreased considerably (a drop from the top to the bottom) in comparison to the previous survey. They assess production profitability much more negatively than in the previous survey $(4.62 \%$ of the answers-last but one position). Organic farmers indicated the use of labor force as an important factor in light of social values: it is related to retaining jobs and sources of livelihood in rural areas. Consequently, it contributes to external social sustainability, explained by Manara and Zabaniotou [25].

The most important barriers for further development of organic agriculture are connected with its profitability, distribution system, and with bureaucratic procedures (Figure 5), however, the differences in the perception of these factors by both groups of farmers are worth noting. They were assessed as obstacles by a remarkably greater percentage of organic farmers than conventional ones. The difference 
is 23 percentage points in the case of distribution system and 10 percentage points in the case of bureaucratic obstacles. Similar differences in the ratings by both groups are noticeable for production profitability and sales possibilities. The entities directly participating in the market encounter problems related to selling their products to processing facilities, shops, or intermediaries on an ongoing basis and struggle with the obligation to satisfy administrative requirements. Their opinions seem to be closer to the reality. Conventional farmers have no experiences in this matter and, therefore, fewer of them notice these barriers to the functioning of organic farming.

The context of the problem of bureaucratic obstacles is broader and it is associated with the scheme of subsidies disbursed to organic farms. As was demonstrated before, it was subject to change in a manner contributing to the diminishing number of farms and cultivated area from 2013. Administrative and bureaucratic procedures discourage farmers on the one hand and there should be a protection against abuse in applying for subsidies on the other hand. Given the fact that they proved to be ineffective in many cases, their improvement needs to be considered one of the conditions for growth in the actual potential of organic production.

In 2019, most of the factors included in the questionnaire were assessed as the chances of development of organic production by a smaller number of conventional and organic farmers than in 2011 (Table 3). Farmers might present a less optimistic approach to organic farming than they did eight years before, since they are discouraged by the conditions of supporting production (including the EU subsidies) within the subsidy scheme and distribution possibilities. The unfavorable assessment of the distribution system as an opportunity for development by both groups of farmers (Table 3) and perception of the system as the main barrier to development according to organic farmers (Figure 5) encourage the conclusion that farmers expect a growth in the demand for organic products, yet the resulting impulse for customers encounters barriers in intermediary links of the food supply chain-processing and sales. As the same in both surveys, organic farmers assessed time growing environmental awareness of consumers and popularity of organic consumption patterns as the biggest chances for development of organic agriculture. Perhaps, the growing demand among consumers will translate into the development of the distribution system, but it has not ensured properly high revenue to date. Given the fact that the development of organic farming involves generation of social benefits (in particular, ones related to environmental services) and social values are the most important factors encouraging farmers to take up organic production (Figures 2 and 3), it is reasonable to enhance and streamline the subsidies from the European Union's Common Agricultural Policy. As was shown before, it has not been a strong impulse for increasing the production potential in the circumstances of low profitability and high costs of production (Figures 4 and 5). In this situation, in light of the principles of internationalization of external effects, it is necessary to raise the subsidy rates, which would compensate for additional costs in organic production. This expected by most of the surveyed farmers.

According to the results of the survey presented in the previous section, a much bigger part of organic farmers took part in the trainings on organic agriculture (and found them useful) than in the group of conventional farmers. It showed that the trainings could help to make the decision to convert to organic farming and to overcome barriers for its development connected with bureaucracy (including the subsidy scheme) or difficult procedures or applying methods of production (Figure 5). They could also improve the labor force and help to increase its input in organic production, which was assessed as one of the incentives of conversion into organic farming (Figures 3 and 4). In 2011, a much bigger percentage of organic farmers took part in the trainings than in 2011. This could mean that they were not available for a significant group of farmers in 2019. About $26 \%$ respondents in both groups did not have possibilities to attend the trainings (35.3\% organic and $63.1 \%$ conventional farmers found them useless), so one of the tasks for public administration is to make them available for a bigger number of farmers and to improve their quality. This would contribute to the improvement of qualifications and better education level as well as to easier use of organic methods of production. Consequently, they could be important factors of external social sustainability mentioned in Section 3.2. 
Integration of farmers in the form of producer groups could be a step towards a kind of social enterprise. Polish farmers were interested in that form of activity. However, a retrograde step was recorded in 2014. This is because financing within the Common Agricultural Policy changed substantially and, starting from 2015, the principles for the support of group formation were less favorable to farmers. Under the Rural Development Programme 2014-2020, preferences for a larger number of farmers integrated into one group were introduced and the farmers who were smaller group members in the previous programming periods were excluded from the system of financial support. There were only seven producer groups established for organic products, with 89 farmers as members in Poland in 2016. The integration level of organic farmers was very low: merely four out of a thousand organic farmers belonged to producer groups. The development of organic farming did not involve the development of an organized organic product processing and trade network [52] (p. 51).

This approach can change in connection with the development of organic farming. The products eligible for public support in Poland include high quality products covered by Article 16 of the Regulation (EU) of the European Parliament and of the Council no. 1305/2013 [53], in particular, organic farming products. The conditions of the support for producer groups include also the elements considered to belong to the social dimension of a social enterprise. The support is addressed to new groups of agricultural producers. Preference is given to farmers organized in cooperatives and the groups need to have at least ten members and be based in a powiat with high agricultural fragmentation. The intention to employ at least two people full time under employment contracts or at least one disabled person under an employment contract is rewarded. Moreover, in granting financial aid, preference is given to the projects where business plans provide for investment projects contributing to the achievement of the cross-cutting objectives of the support program:

- Innovativeness: by introducing new principles of production, process or technology, which are different from the ones applied at present, or changing the currently applied technologies, or

- Climate change prevention or environmental protection: by using machinery, devices, equipment, or technologies reducing environmental impact, or solutions reducing the consumption of resources, in particular, water or energy.

Undoubtedly, further systemic changes regarding the support for producer groups of organic farmers are necessary. Brodzińska [52] stated that organic production required spatial concentration which should facilitate the development of agricultural and food processing and organization of the organic food market, in particular, support for marketing, promotion, and the distribution system. Horizontal integration (producer groups) would help to overcome the obstacles for organic farming enumerated in Section 3 of this paper. It is particularly important in the context of the possibilities of benefiting from the natural conditions that are favorable to this production system (high humus content, uncontaminated soil). What justifies the increase in such support is social values as perceived by conventional farmers interested in converting their farms to the production methods involved in organic farming.

In the European Union, one of the conditions for recognizing a farmer association as a producer group is the principle that each group member produces and sells to the group, in the successive years of the group's operation. At least $80 \%$ of the products or groups of products they manufacture are the ones with regard to which the group was established. The official recognition of the group requires that it pursues one of the goals, which include environmental protection. An officially recognized producer organization gains access to the program of financial support granted by a given member state.

In the framework of the European Innovation Partnership for Agricultural Productivity and Sustainability (EIP-AGRI), operational groups are supported. They are intended to bring together multiple actors such as farmers, researchers, advisers, businesses, environmental groups, consumer interest groups or other NGOs to advance innovation in the agricultural and forestry sectors [54]. In Poland, 31 such groups functioned in 2020. Only two were involved in cooperation between producers and consumers (innovative model of cooperation of agricultural producers in the framework 
of short supply chains and creation of modern model of agricultural products sale). The others referred to product innovations [55]. It shows the need for wider inclusion of social aspects in criteria of innovative project financing. They could consider layouts and measures used in the framework of the National Rural Network (NRN) Joint Thematic Initiative on Social Farming [56].

According to the results of the survey, $11.5 \%$ of the conventional farmers and $12.3 \%$ of the organic farmers belong to a producer group or intend to join such a group. The problem of farmers' demotivation for converting conventional farms into the organic profile was perceived mainly from the economic point of view. This concerned also producer groups. The surveyed organic farmers indicated most frequently that high dispersion of farms was an obstacle in forming producer groups (see Table 4). Almost half of them presented the opinion that the lack of proper government support was another barrier. It could counteract barriers of horizontal integration [57] and stimulate changes which would similar to those observed in South Korea [58].

\section{Conclusions}

Organic farming in Poland represents numerous economic characteristics which, according to the theory, should be demonstrated by social enterprises: an ongoing business producing goods and providing sales services, a high level of autonomy, a high level of economic risk, and a minimum amount of paid labor. The social aspects of the activity include benefiting from local advantages for the wellbeing of animals and the possibilities of increasing the number of farmers by organic farming.

The presented findings of the authors' own surveys indicate that organic farming methods could cover between $5 \%$ and $15 \%$ of farms (in the most optimistic version, with the assumption that all persons interested in yet undecided about organic farming will be certified). The crucial incentives for farmers to commence production are related to social values. This concerns care for the natural environment and family health. Given the described opportunities and barriers as well as drawbacks of the present support policy, it seems, however, that the realistic potential of the organic farms' share in the total number of farms in the medium-term is closer to the lower limit of the specified range. In this variant, the volume of organic products would account for a small part of the market, yet it would allow the satisfaction of the needs of more aware and demanding consumers.

A comparison of the farmers' answers given in 2011 and 2019 encourages the following general conclusions:

- Social values might be the leading premise for making a production shift from the conventional to the organic model;

- Organic farms are more oriented towards social values than conventional ones;

- A prerequisite for maintaining the orientation of farming towards social values must be a guarantee of secure and sustainable economic bases for the operation of organic farming;

- Increase in the dynamics of the development of organic farming on the supply side is conditioned on demand growth (a market factor) or subsidy increase (a factor arising from the agricultural policy), or a combination of both these factors.

A remarkable chance for the development of organic production is the expected demand growth associated with social values - the increasing environmental awareness and environmental change in consumption patterns. However, it is not a sufficient factor for ensuring the economic grounds for production development. For the further development of organic farming, the support within the subsidy scheme provided for in the European Union's Common Agricultural Policy needs to increase and be streamlined and formed in a stable manner such that it could stop being a barrier to enhanced production potential. There is also the need for better system of trainings on organic methods and related procedures. They would improve qualifications, increase the level of education and the use of labor force in rural areas, and consequently, would contribute to social sustainability. If the distribution systems developed properly, the organic food market would come out of its seed state (where it is virtually insignificant at the macro-level), yet it would be a niche. 
The social values declared by farmers might constitute the basis for taking joint actions within producer groups, cooperatives, and other organizational forms of entrepreneurship of a social nature. Farmers coming together in social enterprises would enhance their economic power and have a positive influence on operation sustainability. Thus, it would implement the social values represented not only by farmers themselves but also, and foremost, by consumers, who are characterized by a continuously increasing environmental awareness.

We take into consideration the limitations of our study. The structure of the research sample did not take into account neither the natural conditions of the different regions of the country nor the production volumes in each region. Consequently, the results of the surveys did not indicate whether there was potential for organic farming in the regions with the highest production potential or high environmental values. The project with the test sample, depending on the regions with high agricultural production potential on the one hand and the high natural values on the other hand, and subsequent comparison of the obtained results may be a desirable direction of future research. However, it would require a different research concept and a much larger sample size in regions characterized by concentration of production and, consequently, a larger sample size for the whole country.

We also could conduct surveys not applying to the whole country, but related to selected regions with the highest production value. Industrial agriculture with limited potential to be converted into organic production dominates the regions with the highest volume of production. It applies, for example, to Wielkopolskie voivodship. According to data from the Agricultural Statistical Yearbook 2019 [40], this is $12 \%$ of Polish agricultural land and $8.7 \%$ of the total number of Polish farms which produce the largest part of the national gross agricultural output (17.4\%). At the same time, there are only $4.4 \%$ organic farms and $6.1 \%$ organic farmland in that region. Mazowieckie voivodship has the same share in Polish gross agricultural output as Wielkopolskie $(17.4 \%)$, but there are more conventional farms $(16.6 \%)$ and a larger agricultural area (14.5\%). This means that these farms are less productive. At the same time, there has $12.8 \%$ Polish organic farms and $8.2 \%$ organic farmland. These two regions could be the subject of future comparative studies on the potential for the development of organic production.

We also included the option conditioned by environmental aspect (clean environment in the farm area). It was aimed at investigation if framers took into account environmental pollution and high nature value areas as the incentives to start organic production. These items had a multi-dimensional nature and cannot bring "hard", specified results. We planned to gather the farmers general opinions on the role of indicated aspects in their decision-making. In the future surveys, we will specify the options of answers in a way which will make them possible to obtain more detailed results. We will also take into consideration more economic factors (capital and investments) as well as the other important aspects of social sustainability which were not included in the surveys-social inclusion or farmers' relations with health agencies and employment centers.

Author Contributions: Conceptualization, K.K. and A.G.; resources, K.K. and A.G.; methodology, K.K.; investigation, A.G., K.K. and M.S.; formal analysis, K.M.-Ł.; data curation, K.M.-Ł.; writing-original draft preparation, K.K.; writing - review and editing, K.K. and A.G.; supervision, K.M.-Ł. and M.S. All authors have read and agreed to the published version of the manuscript.

Funding: This paper was financed by the Ministry of Science and Higher Education in Poland under the programme "Regional Initiative of Excellence" 2019-2022 project number 015/RID/2018/19 total funding amount 10721 040,00 PLN.

Conflicts of Interest: The authors declare no conflict of interest.

\section{References}

1. European Commission. A Farm to Fork Strategy for a fair, healthy and environmentally friendly food system. In Communication from the Commission to the European Parliament, the Council, the European Economic and Social Committee and the Committee of the Regions; European Commission: Brussels, Belgium, 2020. 
2. Tuomisto, H.L.; Hodge, I.D.; Riordan, P.; Macdonald, D.W. Does organic farming reduce environmental impacts? A meta-analysis of European research. J. Environ. Manag. 2012, 112, 309-320. [CrossRef] [PubMed]

3. Weisbrod, B.A. Toward a Theory of the Voluntary Nonprofit Sector in a Three-Sector Economy. In The Economics of Nonprofit Institutions; Rose-Ackerman, S., Ed.; Oxford University Press: New York, NY, USA, 1986.

4. Anheier, H.K. Nonprofit Organizations. Theory, Management, Policy; Routledge: London, UK, 2005.

5. Pestoff, V. Co-production and Third Sector Social Services in Europe: Some Concepts and Evidence. Volunt. Int. J. Volunt. Nonprofit Organ. 2012, 23, 1102-1118. [CrossRef]

6. Defourny, J.; Nyssens, M. The EMES Approach of Social Enterprise in a Comparative Perspective. In Social Enterprise and the Third Sector: Changing European Landscapes in a Comparative Perspective; Defourny, J., Hulgård, L., Pestoff, V., Eds.; Routledge: London, UK, 2014; pp. 42-65.

7. Martin, R.L.; Osberg, S. Social Entrepreneurship: The Case for Definition. In Stanford Social Innovation Review; Spring: Stanford, CA, USA, 2007; pp. 29-39. Available online: https://docs.google.com/viewerng/viewer?url=https://community-wealth.org/sites/clone.community-W ealth.org/files/downloads/2007SP_feature_martinosberg.pdf (accessed on 15 March 2020).

8. Defourny, J. From the Third Sector to Social Enterprise. In The Emergence of Social Enterprise; Borzaga, C., Defourny, J., Eds.; Routledge: London, UK, 2001; pp. 17-31.

9. Defourny, J. From Third Sector to Social Enterprise. A European Research Trajectory. In Social Enterprise and the Third Sector: Changing European Landscapes in a Comparative Perspective; Defourny, J., Ed.; Routledge: London, UK, 2014; pp. 17-41.

10. Hassink, J.; van Dijk, M. Farming for Health: Green Care-Farming across Europe and the United States of America; Springer: Dordrecht, Netherlands, 2006.

11. Hine, R.; Peacock, J.; Pretty, J. Care Farming in the UK: A Scoping Study. Report for the National Care Farming Initiative; University of Essex: Colchester, UK, 2008. Available online: http://www.carefarminguk.org/sites/ca refarminguk.org/files/UK\%20Care\%20Farming\%20Research\%20Study.pdf (accessed on 15 March 2020).

12. Hine, R.; Peacock, J.; Pretty, J. Care Farming in the UK: Contexts, benefits and links with therapeutic communities. Ther. Communities 2008, 29, 245-260.

13. Gizicki-Neundlinger, M.; Güldner, D. Surplus, scarcity and soil fertility in pre-industrial Austrian agriculture-The sustainability costs of inequality. Sustainability 2017, 9, 256. [CrossRef]

14. Sulewski, P.; Kołoczko-Gajewska, A.; Sroka, W. Relations between Agri-Environmental, Economic and Social Dimensions of Farms' Sustainability. Sustainability 2018, 10, 4629. [CrossRef]

15. Bacon, C.M.; Getz, C.; Kraus, S.; Montenegro, M.; Holland, K. The social dimensions of sustainability and change in diversified farming systems. Ecol. Soc. 2012, 17, 41. [CrossRef]

16. Hudcova, E.; Chovanec, T.; Moudry, J. Social Enterpreneurship in Agriculture, a Sustainable Practice for Social and Economic Cohesion in Rural Areas: The Case of the Czech Republic. Eur. Countrys. 2018, 10, 377-397. [CrossRef]

17. International Assessment of Agricultural Knowledge, Science and Technology for Development (IAASTD). Agriculture at a Crossroads_IAASTD Synthesis Report; Island Press: Washington, DC, USA, 2009. Available online: http://www.unep.org/dewa/agassessment/reports/IAASTD/EN/Agriculture\%20at\%20a\%20 Crossroads_Synthesis\% (accessed on 10 March 2020).

18. Seufert, V.; Ramankutty, N.; Folley, J.A. Comparing the yields of organic and conventional agriculture. Nature 2012, 484, 229-232. [CrossRef]

19. MacRae, R.J.; Frick, B.; Martin, R.C. Economic and social impacts of organic production systems. Can. J. Plant Sci. 2007, 87, 1037-1044. [CrossRef]

20. Castellini, C.; Bastianoni, S.; Granai, C.; dal Bosco, A.; Brunetti, M. Sustainability of poultry production using the energy approach: Comparison of conventional and organic rearing systems. Agric. Ecosyst. Environ. 2006, 114, 343-350. [CrossRef]

21. Mani VAgarval, R.; Gunasekaran, A.; Papadopulos, T.; Dubey, R.; Childe, S.J. Social sustainability in the supply chain: Construct development and measurement validation. Ecol. Indic. 2016, 71, 270-279. [CrossRef]

22. Weingaertner, C.; Mober, A. Exploring social sustainability: Learning from perspectives on urban development and companies and products. Sustain. Dev. 2014, 22, 122-133. [CrossRef]

23. Van Calker, K.J.; Berentsen, P.B.M.; Giesen, G.W.J.; Huirne, R.B.M. Identifying and ranking attributes that determine sustainability in Dutch dairy farming. Agric. Hum. Values 2005, 22, 53-63. [CrossRef] 
24. Dillon, E.J.; Hennessy, T.; Buckley, C.; Donellan, T.; Hanrahan, K.; Moran, B.; Ryan, M. Measuring progress in agricultural sustainability to support policy-making. Int. J. Agric. Sustain. 2016, 14, 31-44. [CrossRef]

25. Manara, P.; Zabaniotou, A. Indicator-based economic, environmental, and social sustainability assessment of a small gasification bioenergy system fuelled with food processing residues from the Mediterranean agro-industrial sector. Sustain. Energy Technol. Assess. 2014, 8, 159-171. [CrossRef]

26. Amaral, S.P.; La Rovere, E.L. Indicators to evaluate environmental, social, and economic sustainability: A proposal for the Brazilian oil industry. Oil Gas J. 2003, 101, 30-35.

27. Veldhuizen, L.J.L.; Berentsen, P.B.M.; Bokkers, E.A.M.; de Boer, I.J.M. A method to assess social sustainability of capture fisheries: An application to a Norwegian trawler. Environ. Impact Assess. Rev. 2015, 53, 31-39. [CrossRef]

28. Torres, J.; Belmonte, L.J.; Herrero-Sanches, S. Economic and Social Sustainability through Organic Agriculture: Study of the Restructuring of the Citrus Sector in the "BajoAndarax" District (Spain). Sustainability 2016, 8, 918. [CrossRef]

29. Zegar, J.S. Social objectives in sustainable agricultural and rural development policy. In From the Research on Socially-Sustainable Agriculture (48), The Multi-Annual Programme 2015-2019 The Polish and the EU Agricultures 2020+. Challenges, Chances, Threats, Proposals; Kwasek, M., Zegar, J.S., Eds.; Institute of Agricultural and Food Economics-National Research Institute: Warsaw, Poland, 2018.

30. Eizenberg, E.; Jabareen, Y. Social sustainability: A new conceptual framework. Sustainability 2017, 9, 68. [CrossRef]

31. Czyżewski, B.; Kłodowska, M.; Matuszczak, A.; Matuszewska, A.; Śmidoda, D. Social Sustainability in Agricultural Farms with Selected Types of Production in European Union Countries. Annals 2018, XX, 35-40. [CrossRef]

32. Casagrande, M.; Peigné, J.; Payet, V. Organic farmers' motivations and challenges for adopting conservation agriculture in Europe. Org. Agric. 2016, 6, 281-295. [CrossRef]

33. Röös, E.; Fischer, K.; Tidåker, P.; Nordström Källström, H. How well is farmers' social situation captured by sustainability assessment tools? A Swedish case study. Int. J. Sustain. Dev. World Ecol. 2019, 26, 268-281. [CrossRef]

34. Knapik, W. Wybrane aspekty rozwoju polskich obszarów wiejskich na tle koncepcjizrównoważonego rozwoju oraz zakorzenionych rynków (Selected aspects of the development of Polish rural areas against the background of the concept of sustainable development and rooted markets). Roczniki Naukowe SER iA 2014, XVI, 109-113.

35. Czerna-Grygiel, J. Uwarunkowania zrównoważonego rozwoju społeczności lokalnej. In Zrównoważony rozwój obszarów wiejskich. Wybrane Aspekty Społeczne (Sustainable Development of Rural Areas. Selected Social Aspects); Kryk, B., Ed.; Economicus: Szczecin, Poland, 2010; pp. 73-92.

36. Koesling, M.; Flaten, O.; Lien, G. Factors influencing the conversion to organic farming in Norway. Int. J. Agric. Resour. Gov. Ecol. 2008, 7, 78-95. [CrossRef]

37. Matuszczak, A.; Janiak, R.; Muszalska BNowicki, J.; Pawlaczyk, K. Social Sustainability in Agricultural Farms in FADN European Regions. Roczniki Ekonomiczne Kujawsko-Pomorskiej Szkoły Wyższej w Bydgoszczy; 2018, 11, 375-382.

38. European Commission. A Framework for Indicators for the Economic and Social Dimensions of Sustainable Agriculture and Rural Development; European Commission: Brussels, Belgium, 2001.

39. Statistics Poland. Statistical Yearbook of Agriculture. 2018. Available online: https://stat.gov.pl/en/topics/ statistical-yearbooks/statistical-yearbooks/statistical-yearbook-of-agriculture-2018,6,13.html (accessed on 6 July 2020).

40. Statistics Poland. Statistical Yearbook of Agriculture. 2019. Available online: https://stat.gov.pl/en/topics/ statistical-yearbooks/statistical-yearbooks/statistical-yearbook-of-agriculture-2019,6,14.html (accessed on 6 July 2020).

41. Inspekcja Jakości Handlowej Artykuów Rolno-Spozywczych. Condition of Organic Farming in Poland. The Report 2011-2012; IJHARS: Warszawa, Poland, 2013.

42. Inspekcja Jakości Handlowej Artykuów Rolno-Spozywczych. The Report on Organic Farming in Poland 2017-2018; IJHARS: Warszawa, Poland, 2019. 
43. Zieliński, M. (Ed.) Przedsiębiorstwo i Gospodarstwo Rolne Wobec Zmian Klimatu i Polityki Rolnej (5) (Company and Farm on Climate Change and Agricultural Policy), The Multi-Annual Programme 2015-2019, The Polish and the EU Agricultures 2020+; Challenges, chances, threats, proposals, Institute of Agricultural and Food Economics-National Research Institute: Warsaw, Poland, 2018; pp. 161-171.

44. Inspekcja Jakości Handlowej Artykuów Rolno-Spozywczych. Condition of Organic Farming in Poland. The Report 2013-2014; IJHARS: Warszawa, Poland, 2015.

45. Inspekcja Jakości Handlowej Artykuów Rolno-Spozywczych. Liczba Producentów Ekologicznych w Polsce, w Podziale na Kategorie Działalności, wg Stanu na 31 Grudnia 2015 r.; IJHARS: Warszawa, Poland, 2016.

46. Inspekcja Jakości Handlowej Artykuów Rolno-Spozywczych. Liczba Producentów Ekologicznych w Polsce, w Podziale na Kategorie Działalności, wg Stanu na 31 Grudnia 2016 r.; IJHARS: Warszawa, Poland, 2017.

47. Inspekcja Jakości Handlowej Artykuów Rolno-Spozywczych. Liczba Producentów Ekologicznych w Polsce, w Podziale na Kategorie Działalności, wg Stanu na 31 Grudnia 2017 r.; IJHARS: Warszawa, Poland, 2018.

48. Willer, H.; Lernoud, J. (Eds.) The World of Organic Agriculture: Statistics and Emerging Trends 2019; Frick Research Institute of Organic Agriculture (FIBL), and IFOAM—Organics International: Bonn, Germany, 2019.

49. Najwyższa Izba Kontroli. Wspieranie Rozwoju Rolnictwa Ekologicznego. Informacja o Wynikach Kontroli; NIK: Warszawa, Poland, 2019.

50. Heinrich Boll Foundation. Agriculture Atlas 2019 Facts and Figures on EU Farming Policy; Friends of the Earth Europe, BirdLife Europe \& Central Asia: Brussels, Belgium, 2019.

51. Fiedor, B.; Kociszewski, K. (Eds.) Ekonomia Rozwoju (Development Economics); Wydawnictwo Uniwersytetu Ekonomicznego: Wrocław, Poland, 2010.

52. Brodzińska, K. System wsparcia rolnictwa ekologicznego i grup producentów rolnych-Założenia i implikacje praktyczne. Roczniki Naukowe Stowarzyszenia Ekonomistów Rolnictwa i Agrobiznesu 2017, 19, 48-53. [CrossRef]

53. European Parliament, Council of the European Union. Regulation (EU) No. 1305/2013 of the European Parliament and of the Council of 17 December 2013 on Support for Rural Development by the European Agricultural Fund for Rural Development (EAFRD) and repealing Council Regulation (EC) No. 1698/2005 (OJ L 347/887 20.12.2013). Available online: https://eur-lex.europa.eu/LexUriServ/LexUriServ.do?uri=OJ:L: 2013:347:0487:0548:en:PDF (accessed on 20 December 2013).

54. European Commission. About EIP-AGRI; European Commission: Brussels, Belgium, 2018. Available online: https://ec.europa.eu/eip/agriculture/en/about (accessed on 7 July 2020).

55. Projects Database in CDR Brwinów (Agricultural Advisory Centre in Brwinów)—EIP Operational Groups. 2020. Available online: https://sir.cdr.gov.pl/partnerzy/pr_szukaj_en.php (accessed on 7 July 2020).

56. O'Connor, D.; Lai, M.; Watson, S. Overview of Social Farming and Rural Development Policy in Selected EU Member States. 2010. Available online: https://enrd.ec.europa.eu/enrd-static/fms/pdf/A9746FA3-0D7E-1772 -5CC7-11217C8EC059.pdf (accessed on 6 July 2020).

57. Boulding, K.E. Czy ekonomia jest niezbędna? In Ponad Ekonomia; Boulding, K.E., Ed.; PIW: Warszawa, Poland, 1985; pp. 31-39.

58. Hansalim Model of South Korea. Available online: http://www.stories.coop/stories/written/hansalim (accessed on 23 September 2013).

(C) 2020 by the authors. Licensee MDPI, Basel, Switzerland. This article is an open access article distributed under the terms and conditions of the Creative Commons Attribution (CC BY) license (http://creativecommons.org/licenses/by/4.0/). 